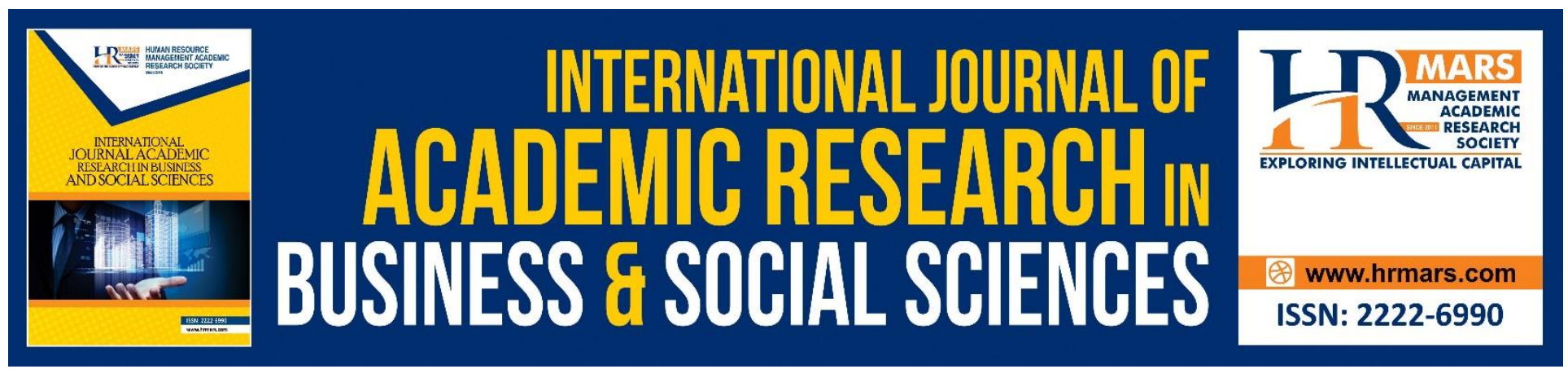

\title{
The Effectiveness of Learning Assessment Instrument (LAl) Based on Teaching Games for Understanding (TGFU) for Badminton Games
}

\author{
Mohd Izwan Shahril, Julismah Jani, Norkhalid Salimin, Wawan \\ Suherman, Guntur
}

To Link this Article: http://dx.doi.org/10.6007/IJARBSS/v9-i6/5924

DOI: 10.6007/IJARBSS/v9-i6/5924

Received: 15 April 2019, Revised: 02 May 2019, Accepted: 24 May 2019

Published Online: 23 June 2019

In-Text Citation: (Shahril, Jani, Salimin, Suherman, \& Guntur, 2019)

To Cite this Article: Shahril, M. I., Jani, J., Salimin, N., Suherman, W., \& Guntur. (2019). The Effectiveness of Learning Assessment Instrument (Lai) Based On Teaching Games for Understanding (Tgfu) for Badminton Games. International Journal of Academic Research in Business and Social Sciences, 9(6), 90-97.

Copyright: (c) 2019 The Author(s)

Published by Human Resource Management Academic Research Society (www.hrmars.com)

This article is published under the Creative Commons Attribution (CC BY 4.0) license. Anyone may reproduce, distribute, translate and create derivative works of this article (for both commercial and non-commercial purposes), subject to full attribution to the original publication and authors. The full terms of this license may be seen at: http://creativecommons.org/licences/by/4.0/legalcode

$$
\text { Vol. 9, No. 6, 2019, Pg. } 90 \text { - } 97
$$

Full Terms \& Conditions of access and use can be found at http://hrmars.com/index.php/pages/detail/publication-ethics 


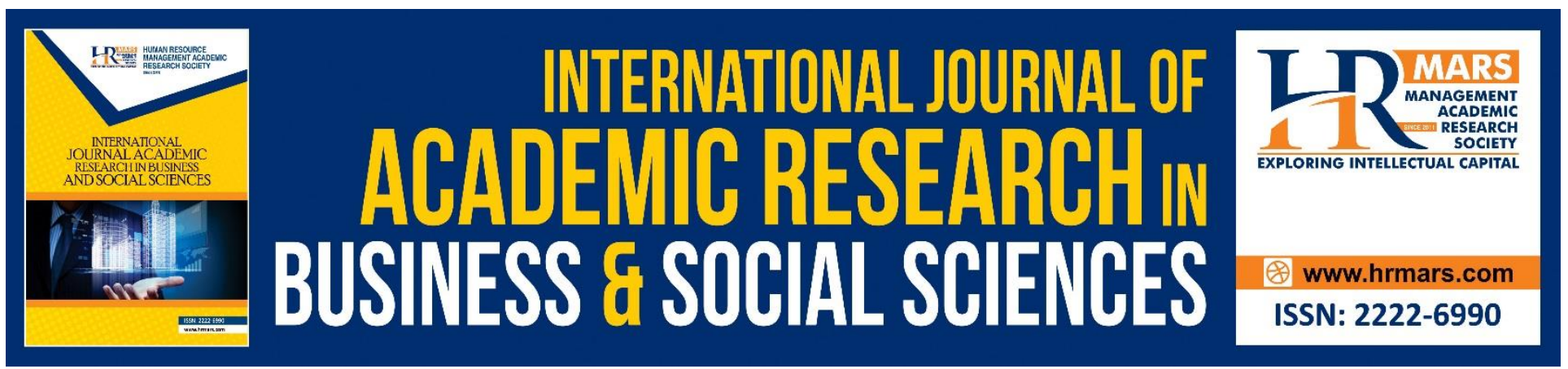

\title{
The Effectiveness of Learning Assessment Instrument (LAI) Based on Teaching Games for Understanding (TGFU) for Badminton Games
}

\author{
Mohd Izwan Shahril ${ }^{1}$, Julismah Jani ${ }^{1}$, Norkhalid Salimin ${ }^{1}$, Wawan \\ Suherman², Guntur ${ }^{2}$ \\ ${ }^{1}$ Faculty of Sports Science and Coaching, Sultan Idris Education University, Malaysia \\ ${ }^{2}$ Faculty of Sports Science, Yogyakarta State University, Indonesia
}

\begin{abstract}
The aim of this study was to determine the effectiveness of Learning Assessment Instrument (LAI) for badminton games based on Teaching Games for Understanding (TGfU) in Physical Education (PE) subject. Present findings showed high validity and reliability of LAI when comparing students' learning achievement. The students' learning achievements of cognitive, psychomotor and affective aspects were performed very well at Band 5 . This study also revealed there were no significant differences between boarding schools, religious schools and daily schools, but there was a strong relationship with students' achievement. In conclusion, LAl was found to be very effective and can be used as a standard measurement in student's reasoning activity and guide teachers in teaching and learning assessment.
\end{abstract}

Keywords: Badminton, Learning Assessment Instrument (LAI), Teaching Games for Understanding (TGfU).

\section{Introduction}

The implementation of Standard-Based Curriculum introduced by the Ministry of Education is a transformation aimed to enhance the quality of students. With that, the transformation of the teaching and learning process and student-centered assessment methods need to be considered in all school levels. Consequently, the Learning Assessment Instrument (LAI) model is built specifically for teachers and future educators and individuals who will be directly involved in the field of education during the assessing and evaluating students process in Physical Education (PE). This model of reasoning for nets and walls category games is built based on Teaching Games for Understanding (TGfU) method. TGfU concept is pioneered by Bunker and Thorpe (1982), which is a teaching approach that emphasizes on the understanding of tactics and play strategies before the mastery of technique skills (Araujo et al, 2004; Bunker \& Thorpe, 1982; Griffin, Mitchell, \& Oslin 1997). 
The approaches of TGfU model involves an improvised technique when students master the tactics and strategy technically during the TGfU game. Skills are introduced in the form of games and not drillings for the skill itself. In this context, the concept of TGfU in the perspective of Malaysian Physical Education is almost equal to the organizing of mini sports or small games. In short, this allows and facilitates the students' understanding process and motivates the students to learn skills after exposure to the importance of game skills. A very important matter in TGfU is to understand the philosophy in which the students need to know and understand how the game is beforehand and are able to apply the game skills while mastering the ability to make appropriate decisions based on the situation during the game. The game should be accompanied by a few guided questions so that the students can master the game through problem solving. Group game strategy-centered teaching approaches should be emphasized in TGfU. Thus, LAl is adapted to TGfU concept so that the teaching and learning process can measure the students' performance more effectively. TGfU model cycle is used as criteria in evaluating students' performance.

Revised Bloom's Taxonomy (Anderson, Lorin, Krathwohl, 2001) is used as a guide in forming the standard descriptors in Learning Assessment Instrument (LAI) so that the evaluation of the students' performance will be more meaningful. Revised Bloom's Taxonomy is a classification of cognitive domain pioneered by Anderson, Lorin, Krathwohl \& David. (2001). There are six levels of cognitive domain classification starting from the lowest level to the high level of knowing, understanding, applying, analyzing, evaluating and creating. This classification system is levelled so that the students can master the lowest level before reaching the highest level. The main goal of this taxonomy is to apply higher-order thinking skills.

According to Information Processing Theory pioneered by Gagne (1985), stimulus from the external environment will be received in the nervous system through human senses. The information will be interpreted in memory store, then sent to the long-term memory store and eventually to drive the reaction by the nervous system. The process of information processing is considered as a computer, which stimulus input is processed by sensory memory and short term memory. The information result is used to respond to the environment or stored in long term memory. This theory also states that the experiences stored in long term memory storage is important for human to associate them with new experiences to facilitate the taking place of learning process. Based on this theory, the input is the game appreciation received based on the activity. Next, the input is processed in the sensory memory and short-term memory before a decision is made. As a result of these decisions, skills performance is used to react in game situations and this performance is stored in long term memory.

Moreover, affective domain involves the spiritual aspect and emphasizes the growth and development of attitudes, feelings, emotions and values that exist (Krathwohl, Bloom \& Masia Taxonomy, 1964). Feelings, attitudes and values are things to be learned and developed over time. There are five levels of affective domain in the taxonomy, ranging from low to high, contain of receiving, responding, appreciating, organizing and developing character. The affective taxonomy is 
INTERNATIONAL JOURNAL OF ACADEMIC RESEARCH IN BUSINESS AND SOCIAL SCIENCES Vol. 9, No. 6, May, 2019, E-ISSN: 2222-6990 @ 2019 HRMARS

used as a guide in the developing assessment criteria and standard descriptors in LAI model. The criteria in the assessment of LAI model focuses on the values shown during the game.

\section{Method}

Learning Assessment Instrument (LAI) is built based on TGfU Model (Bunker and Thorpe, 1982) to assess the psychomotor domain. In addition, the Revised Bloom's Taxonomy (Anderson, Lorin, Krathwohl, \& David, 2001) and Theory of Information Processing (Gagne, 1975) are as guide in assessing the cognitive domain. Krathwohl, Bloom \& Masia Taxonomy (1964) is used as a guide in assessing the affective domain. The combination of all these resources is used in designing LAl.

\section{Learning Assessment Instrument (LAI)}

LAl model observes four cycles, which are game appreciation, decision-making, skills performance and moral values as showed in Figure 1 . The first cycle, game appreciation is the beginning of LAl model cycle. This cycle explains the rules of the game that need to be mastered by both players who attack and defend. The second cycle of this model is decision making. In this cycle, there are two assessment criteria to be emphasized, that are tactical awareness and strategy awareness. Tactical awareness focuses on the extent the player can show good tactic in the game in either attack or defence position. On the other hand, strategy awareness focuses on the extent the players show creative and good strategy in the game in either attack or defence position. The skills performance as third cycle refers to the passing and receiving skills to be mastered by players in either attack or defend position. This cycle focuses on passing and receiving because it is a key skill for all net and wall category games. Therefore, players need to master this skill as it is one of the assessment criteria in LAI model. Lasly, fourth circle known as moral values should be shown by the players in either attack or defend position during the game. Moral values is the fourth cycle in LAl model. The affective domain is in accordance with the moral values that need to be emphasized in Physical Education.

Figure 2 shows the performance standard of Performance Assessment Instrument (PAI) for assessing the overall performance of students. This standard is used as a reference to assess the overall performance of students after being assessed using the available instruments. There are five levels of performance levels ranging from low level, that is know, understand, apply, master and create. Each level has its standard statement that describes the meaning of the overall performance level. 
INTERNATIONAL JOURNAL OF ACADEMIC RESEARCH IN BUSINESS AND SOCIAL SCIENCES Vol. 9, No. 6, May, 2019, E-ISSN: 2222-6990 @ 2019 HRMARS

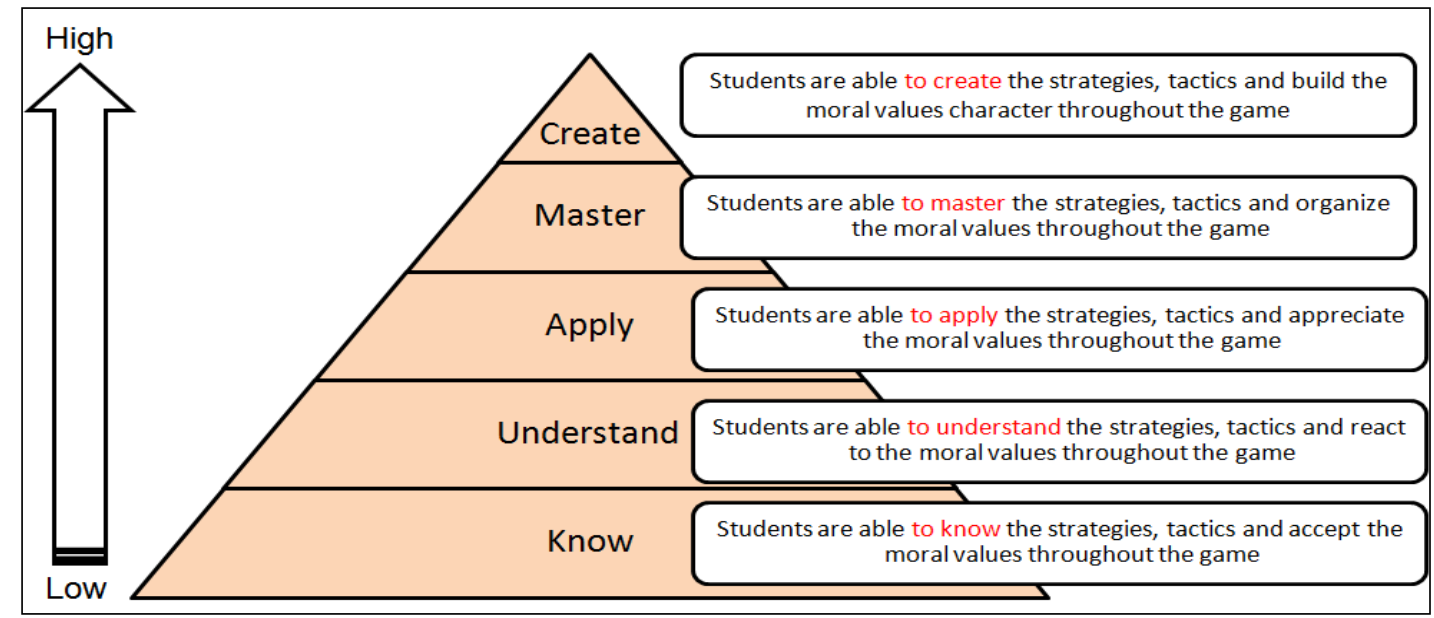

Figure 2 Performance Standard of Performance Assessment Instrument (PAI)

\section{Results and Discussion}

\section{Identify the Validity and Reliability of Examiners (Interobserver Reliability) of LAI}

Table 1 shows the expert panel content item validity to identify the Reliability of Examiners (Interobserver Reliability) of LAI.

Table 1 shows the content item validity of Learning Assessment Instrument (LAI) is $r=0.90$ ( $n=6)$. According to Izwan et. al. (2015) and Norkhalid et. al. (2014) the validity value of 0.70 is considered to have high mastery level.

\begin{tabular}{lllllllllll}
\hline & $\begin{array}{l}\text { Expert } \\
\mathbf{1}\end{array}$ & $\begin{array}{l}\text { Expert 2 } \\
\text { (Conten }\end{array}$ & $\begin{array}{l}\text { Expert } \\
\text { (Conten } \\
\text { t) }\end{array}$ & $\begin{array}{l}\text { (Languag } \\
\text { e) }\end{array}$ & $\begin{array}{l}\text { Expert } \\
\text { (Language } \\
\text { ) }\end{array}$ & $\begin{array}{l}\text { 4 } \\
\text { Item }\end{array}$ & $\begin{array}{l}\text { Expert } \\
\text { (Perform } \\
\text { er) }\end{array}$ & $\begin{array}{l}\mathbf{5} \\
\text { Expert } \\
\text { (Perform } \\
\text { er) }\end{array}$ & $\mathbf{5}$ & $\mathbf{M}$ \\
\hline $\begin{array}{l}\text { Instruction } \\
\text { al Content }\end{array}$ & 0.90 & 0.92 & 0.91 & 0.93 & 0.90 & 0.91 & 5.47 & 0.91 \\
$\begin{array}{l}\text { Design } \\
\text { Technical }\end{array}$ & 0.91 & 0.90 & 0.89 & 0.89 & 0.91 & 0.90 & 5.40 & 0.90 \\
Writing & 0.90 & 0.91 & 0.89 & 0.89 & 0.90 & 0.89 & 5.38 & 0.89 \\
\hline Total & 0.90 & 0.91 & 0.89 & 0.90 & 0.90 & 0.90 & 5.40 & 0.90 \\
\hline
\end{tabular}

Next, the interobserver reliability is run against $(\mathrm{N}=7)$ Physical Education teachers. Full 40 minutes video recordings of teacher's teaching and learning of net and wall category games are assessed by the research sample. Based on the recordings, the samples give marks based on the assessment rubric contained in LAI in the forms provided. This triangulation method ensures that the data obtained can be controlled in terms of consistency among examiners (Izwan et. al., (2015) and Norkhalid et. al. (2014). The interobserver agreement of LAI based on the recording evaluation of one session of 40 -minutes teaching and learning of net and wall category games is between $80.35 \%$ $91.47 \%$, with the percentage of $M=86.57 \%$. According Izwan et. al. (2015), Norkhalid et. al. (2014) 
INTERNATIONAL JOURNAL OF ACADEMIC RESEARCH IN BUSINESS AND SOCIAL SCIENCES Vol. 9, No. 6, May, 2019, E-ISSN: 2222-6990 @ 2019 HRMARS

and Rink (2002), the reliability of adoption is at least 70\% (0.70) agreement between the examiner. The findings shows that LAI can be used as a standard instrument to assess students' performance in accordance with TGfU.

\section{The Comparison of Student's Learning Achievement}

Table 2 shows an independent t-test sample analysis to compare the mean score of student learning achievement by gender using LAI for badminton games based on TGfU. The findings show that there is no significant difference $(p=0.222)$ for mean score of student learning achievement by gender using TGfU based on LAI in badminton games. Data analysis showed that the mean achievement of male students $(M=82.24, S D=9.12)$ is higher than the mean achievement of female students $(M=$ 81.21 , SD $=8.68$ ) based on learning achievement using LAI for badminton game based on TGfU.

Table 2 Student's Learning Achievement by Gender

\begin{tabular}{lllllll}
\hline Gender & $\boldsymbol{N}$ & $\boldsymbol{M}$ & $\boldsymbol{S D}$ & $\boldsymbol{F}$ & $\boldsymbol{T}$ & Sig-p \\
\hline Male & 207 & 82.24 & 9.12 & .103 & 1.223 & .222 \\
Female & 241 & 81.21 & 8.68 & & & \\
\hline
\end{tabular}

* Significant value $p<0.05$

\section{Interobserver Agreement Questionnaires by Teachers}

The effectiveness of LAl was determined through interobserver agreement questionnaires by teachers. There are 7 criteria that are evaluated, that are the use of instruments for students' achievement, the use of teacher assessment, the use of assessment on the achievement of learning objectives, the quality of the instruments, the accuracy of the assessment (accountability), the assessment method and the assessment process. In overall, the level of teacher agreement $(\mathrm{N}=18)$ on LAl usage is $83.71 \%$. According to Izwan et. al. (2015), Norkhalid et. al. (2014) and Rink (2002), the interobserver agreement of adoption is at least $70 \%(0.70)$ agreement between the examiner. The findings shows that LAI can be used as a standard instrument to assess students' performance based on TGfU.

\section{Strength of LAI (Methodological Triangulation)}

The strength of the Learning Assessment Instrument (LAI) is assessed based on the achievement of student learning, expert panel reports and teacher agreeement through methodological triangulation. The level interobserver agreement is used to see the overall assessment percentages for student learning achievement, expert panel reports and teacher consent. Hence, LAI strengths were analyzed based on Bryington et. Al. (2002), Norkhalid et. Al. (2014), and Izwan et.al. (2015) which states that if there is more than one examiner for a test item then the approval percentage method is appropriate for obtaining the value of the instrument.

Based on Figure 3, the percentage of expert panels report is highest (86.57\%) followed by $84.30 \%$ of students' learning achievement and $83.71 \%$ of teachers' interobserver agreement. The overall percentage of mean value for all three values is $84.86 \%$. According to Norkhalid et. Al. (2014), Izwan et. Al. (2014) and Rink (2002), the reliability value adopted is at least $70 \%$ of the agreement between 
INTERNATIONAL JOURNAL OF ACADEMIC RESEARCH IN BUSINESS AND SOCIAL SCIENCES Vol. 9, No. 6, May, 2019, E-ISSN: 2222-6990 @ 2019 HRMARS

examiners. The findings show that the Learning Assessment Instrument (LAI) can be used as one of the standard assessment instruments based on TGfU.

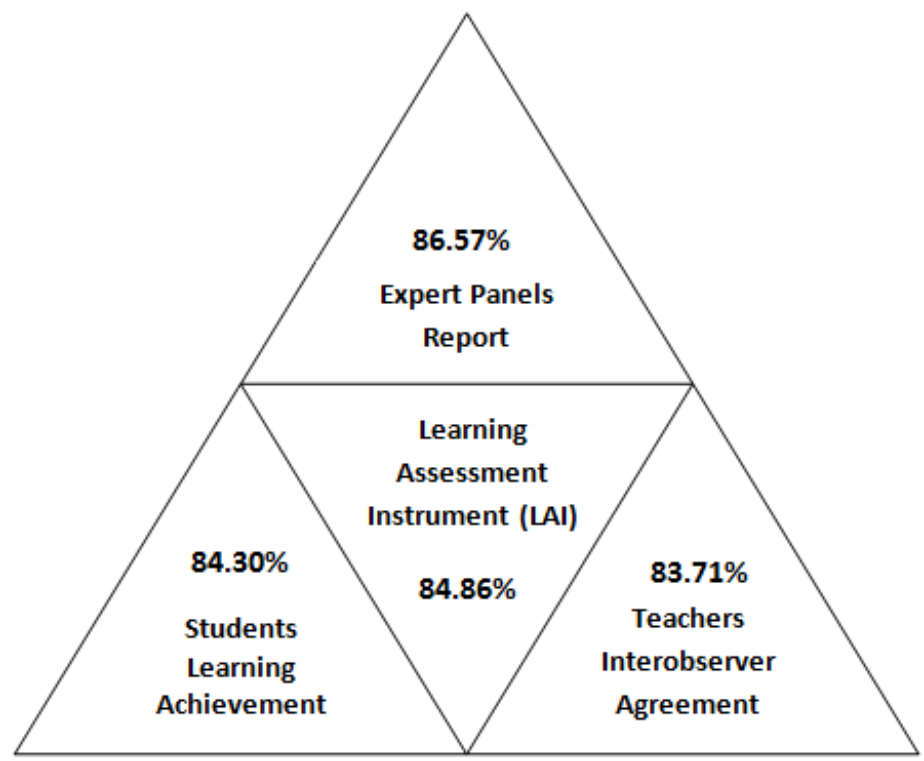

Figure 3 Methodogical Triangulation

\section{Conclusion}

In overall, LAl is suitable to be used as a standard instrument in assessing students' performance level for the badminton games based on TGfU. LAI is able to assess the assessments' quality, evaluate the teachers holistically and give impact on the level of students' achievement in Physical Education in line with the National Education Philosophy in producing a holistic human in terms of physical, emotional, spiritual and intellectual. In addition, in realizing the government's hope for Education Development Plan, especially in terms of reasoning, assessment quality and the evaluation of teachers need to be improved so that students can be assessed more systematically. Therefore, LAI can be used as a guide for teachers to improve the quality of assessment and evaluation in realizing the goal.

\section{References}

Anderson, Lorin W., Krathwohl, \& David R. (2001). A Taxonomy for Learning, Teaching and Assessing: a Revision of Bloom's Taxonomy. New York. Longman Publishing.

Araújo, D., Davids, K., Bennett, S., Button, C., \& Chapman, G. (2004). Emergence of Sport 10 Skills Under Constraint. In A. M. Williams \& N. J. Hodges (Eds.), Skill Acquisition In 11 Sport: Research, Theory and Practice (pp. 409-433). London:Routledge, Taylor \& 12 Francis.

Bunker, D., \& Thorpe, R. (1982). A Model For The Teaching Of Games In Secondary Schools. Bulletin of Physical Education, 18(1), 5-8.

Gagne, R. M. (1985). The Condition of Learning and Theory of Instruction (4th ed.). New York: Holt, Rinehart \& Winston, Inc.

Griffin, L., Mitchell, S., \& Oslin, J. (1997). Teaching Sport Concepts and Skills: A Tactical 
Games Approach. Champaign, IL: Human Kinetics.

Izwan, Norkhalid \& Gunathevan a/I Elumalai (2015). The Validity and Realibility of ISO

Test Toward The Performance Assessment of Future Physical Education Teachers in Teaching and Learning Process. Science Direct Procedia-Social and Behaviorial Sciences 00 (2015) $000-$

Krathwohl, D. R., Bloom, B. S., \& Masia, B. B. (1964). Taxonomy of Educational Objectives

The Classification of Educational Goals, Handbook II: Affective Domain. New York: David McKay Company, Inc.

Salimin, N., Jani, J., Ishak, N.A., \& Hassan, S., Elumalai, G., Boon, O. K., \& Shahril, M. I. (2014). Validity and Reliability of Comprehensive Assessment Instruments for Professional Skills in Field and Court Sport Among Major Students Coaching Based on Model K. International Journal of Humanities, Arts, Medicine and Sciences (BEST: IJHAMS) ISSN(E): 2348-0521 Vol. 2, Issue 4, Apr 2014, 37-44.

Rink, J. E. (2002). Teaching physical education for learning 4th ed. New York: McGraw Hill. Robert Mills Gagné (1975). Essentials of Learning for Instruction: Principles of Educational PsychologySeries. Dryden Press. 